\title{
İdeolojinin Doğuşu ve Bilim-Din Ekseninde Konumlanması
}

\author{
Dr. Saniye VATANDAŞ \\ Isparta Uygulamalı Bilimler Üniversitesi \\ Teknik Bilimler Meslek Yüksek Okulu \\ saniyevatandas@isparta.edu.tr \\ ORCID: 00000-0002-3646-9332
}

\begin{abstract}
Öz
İdeoloji isim açısından tamamen, anlam ve işlevleriyle de büyük oranda modern zamanların bir olgusudur. Düşünsel kökleri Platon'a kadar uzanmakla birlikte, farklı filozofların düşüncelerinden beslenerek gelişimini sürdürmüş ve gerek anlam gerekse kendisinden beklenen işlevleri açısından sistematik bir şekilde ilk kez Aydınlanma çağında inşa olunmuştur. İsmen doğuşu ve ilk sistematik formunu kazanışı Devrim Fransa'sında gerçekleşen ideolojinin bu ilk zamanlardaki anlam ve işlevleri, 14. yüzylldan beri devam etmekte olan geleneksel-modern, din-bilim, eski-yeni, geri-ileri geriliminden pay alarak oluşmuştur. Doğuş aşamasında "düşünce bilimi" anlamına sahiptir. Fakat kısa süre sonra öznesine göre değişen başka anlamlar ve işlevler üstlenmiştir. Bugün itibarıyla neredeyse her bireyin yanı sıra her devletin, toplumun, ülkenin, toplum kesiminin, siyasal ve ekonomik sistemin ideolojik nitelediklerinden bahsedilecek kadar bireysel ve toplumsal düşüncelere, sistemlere, felsefelere, yaşam tarzlarına ilişikli hâle gelmiş durumdadır. Dolayısıyla anlam ve işlevleriyle çok farklı boyutlar kazanmıştır. Bu inceleme ideolojinin Platon'dan başlayan ve Aydınlanma çağına Uzanan süreçteki öncülerini ve Aydınlanma çağındaki inşa sürecini konu edinmektedir.
\end{abstract}

Anahtar Kelimeler: ideoloji, aydınlanma, bilim, din

Vatandaş, S. (2020). İdeolojinin Doğuşu ve Bilim-Din Ekseninde Konumlanması. ARTS: Artuklu Sanat ve Beşeri Bilimler Dergisi, 4, ss. 76-102. 


\title{
Birth of Ideology and Its Position on the Axis of Science-Religion
}

\begin{abstract}
Ideology is entirely a phenomenon of the modern era not only in terms of its 'name' but also of its 'meanings and functions'. Though its intellectual roots go all the way back to Plato, it has continued its development by being fed by the thoughts of different philosophers, and it was built systematically for the first time in the Age of Enlightenment in terms of both its expected meaning and its functions. The birth of the word ideology and its gaining a systematic form for the first time took place at the time of French Revolution. The meanings and functions of ideology in these early times were formed by making use of certain tensions such as traditional-modern, old-new, reactionary-prograsive, religion-science conflict that had been going on since the 14 th century. Previously, it had the meaning of 'science of thought'. But later it took on different meanings and functions which changed according to its subject. As of today, it has become associated with almost every individual, every state, society, country, ethnic group, lifestyle, philosophy, political and economic system. Therefore, its meaning and function has gained many different dimensions. This study focuses on the pioneers of ideology from Plato to the Enlightenment era and on its process of construction in the Enlightenment era.
\end{abstract}

Keywords: ideology, enlightenment, science, religion 


\section{arts $=$}

\section{Gíriş}

İdeolojinin ne olduğu, hemen her zaman sosyal, siyasal, ekonomik, kültürel alanlarda ve akademik, bilimsel çevrelerin gündemlerinde önemli yer edinmiş konulardan birisidir. İdeolojinin ne olduğu ile ilgili verilmiş çok sayıda cevabın yanı sıra, ideolojinin anlamı ve işleviyle ilgili olarak da belirli çevrelerce kabul gören yine çok sayıda tanım bulunmaktadır. İdeolojinin anlam ve işlevine ilişkin farklı anlayış ve yaklaşımlara rağmen, tüm kesimlerde ortak kabul edilen temel özelliklerinden birisinin, ideolojinin modern dönemlere özgü olduğu ve anlamsal inşasının Aydınlanma Çağı ortamında başladığıyla ilgilidir. 14. yüzyılda Hümanist çalışmalarla başlayan ve Aydınlanma ile gelişimini büyük oranda tamamlayan modern zihniyet ve yaşam tarzının ürünü olan ideolojiye ilişkin yaklaşımlardan bazılarına göre ideoloji bir "dünya görüşü"dür. Bireyin evrenle ve toplumla olan ilişkisi iki açıdan ideoloji ile irtibatlıdır. Bunlardan birisi insanın parçası olduğu evreni "anlama ve kontrol etme" intiyacı, ötekisi ise insanın kendisini evrende ve toplumda konumlandırma, niteleme ve hem evren hem de toplum ile ilişkilerini "düzenleme" intiyacıdır. İnsanın evren ile ilişkisinde en önemli nokta, nesnel evrende gerçekleşen olayları gözlemleyerek sebep ve sonuçlarını anlamak ve anlamlandırmak, sınıflamak ve yaşamı hem rahat hem de güvenilir kılma arzusudur. İdeoloji bir bakıma tüm bu arzu ve çabalara karşıllk gelmektedir. Diğer bazı açılardan ise 'düşünce tarzl', 'yaşam biçimi', 'siyasi inanç sistem', 'siyasi fikirler kümesi', 'iktidarın denetim aygıtı', 'kolektif bir eylemi meşrulaştıran düşünceler sistemi', 'siyasi öğreti', 'ekonomik sistem' ... gibi anlamlara gelmektedir.

İdeoloji sözcüğünü ilk kez "ideologlar" grubunun önemli temsilcilerinden Destutt de Tracy ifade etmiş olmakla birlikte, anlamsal ve işlevsel özelliklerine ilişkin geçmişi Platon'a kadar uzanmaktadır. Platon'un 'devlet'in var olmasının ve varlığını problemsiz sürdürebilmesinin temel aracı olarak gördüğü "soylu yalan" tanımlaması, modern zamanların ideolojisinin antik çağdaki öncüsü olarak dikkate alınabilir. Takip eden zamanlarda ideolojinin anlamsal ve işlevsel açıdan inşa sürecinin birçok önemli durağı bulunmaktadır. Bunlar arasında Francis Bacon (1561-1626), Étienne Bonnot de Condillac (1715-1780) ve Claude Adrien Helvétius (1715-1771) ismi ön plana çıan filozoflardır. Bu şahsiyetler, bilgi felsefesi bağlamında "gerçek" olana ulaşmanın araç ve tarzını tartışıllarken, gerçeğin niteliğini irdelerlerken önemli birer öncü olarak ideolojinin inşasına önemli katkılar sağlamışlardır. Böylelikle modern zihniyet ve yaşam 
tarzının felsefi temellerinin inşa edildiği Aydınlanma çağı aynı zamanda ideolojinin de doğum çağı olmuştur. Dolayısıyla ideolojinin doğuşunu sağlayan koşulların ve ideolojinin gerek anlamsal gerek işlevsel temellerini Aydınlanma felsefesinde ve Aydınlanma çağının inanç, din, bilim tartışmalarında aramak gerekmektedir.

Çağlar boyunca insanların, varoluşa, nesnel evrene, ilahi iradeye, topluma ve siyasal iktidara ilişkin sorularını cevaplayan dinler, mitler ve gelenekler söz konusu cevapları önceden hazır bir halde insanlara sunmuşlar; böylece sürmekte olan sosyal ve siyasal düzenin tam da "olması gerektiği gibi" olduğuna ilişkin inanç ve kabulleri desteklemişler, nesnel anlamda mevcut olanları izah ederek "daha iyi bir insan ve toplum nasıl olmalıdır?" sorusuna da cevaplar vermişlerdir. Fakat Avrupa toplumları açısından Orta Çağ, bir dinin cevaplarının şekillendirdiği 'karanlık' bir çağ olmuştur. Çünkü 'gerçek' adına gerçeğe giden tüm yolları kapatmış, sorgulanmasına izin verilmeyen cevaplarıyla dünyayı her yönüyle yeniden inşa ederken, yaşamı bireyler ve toplumlar için katlanılamayacak kadar ağırlaştırmıştır. Aydınlanma ise söz konusu 'karanlıktan' kurtulup 'aydınlığa' erişmenin yolunu aşkın değerlerin; bu değerlerin referansı olan din, tanrı ve kilisenin bireysel ve toplumsal yaşamdan uzaklaştırılmasında görmüş, dinden boşalan alanı ise dolduracak yeni bir inanç sistemine intiyaç hissetmiştir. İdeoloji ise bu ihtiyacın karşılığı olmuştur. Fakat ideoloji özellikle doğup gelişimini hızla sürdürdüğü Aydınlanma çağında hiçbir zaman bir 'inanç' sistemi olarak takdim edilmedi. Hatta felsefe olarak da nitelenmedi. Çağın felsefelerinin ve egemen anlayışlarının gereğine uygun olarak 'gerçek' olanın tek yöntemi kabul edilen bilimle özdeşleştirilip 'düşünce bilimi' olarak nitelendi. Böylelikle din- Aydınlanma felsefesi çatışmasında bilime yakın konumlandııılı.

Bu makale, Aydınlanma çağından bu güne çok farklı boyutlarda anlamsal ve işlevsel değişim ve dönüşüme uğramış olan "ideoloji”nin Aydınlanma çağındaki anlam ve işlevini konu edinmektedir. Anlam ve işleviyle konumlanışı ise özel ilgi noktasını oluşturmaktadır.

\section{İdeoloji}

Eğer ideolojiden bahsediliyorsa, modern zamanlardan bahsediliyor demektir. Çünkü ideoloji, öncü düşüncelere rağmen, modern döneme özgüdür. Sözcük olarak da kavram olarak da bu böyledir. İdeolojinin isim olarak doğuş tarihini net bir 


\section{arts}

şekilde biliyoruz. Ancak anlamına; kavram olarak inşa ediliş sürecine gelince durum değişiyor. İsim/sözcük olarak inşası öncesinde de sonrasında da durum oldukça karışık. Zira ideolojiye yüklenen anlamlar zaman içerisinde çok farklı mecralardan geçti. Bu sebeple çok farklı kavramlaştırmalara sahip oldu. Dolayısıyla ideolojinin olumlu veya olumsuz, dar veya geniş anlamlarda birçok tanımı ile karşılaşınca şaşırmamak gerekiyor. Bunlara örnek olması ve kavramsal açıdan genel bir zemin oluşturmak adına, bugün itibarıyla ideoloji denildiğinde dile getirilen ve yaygın olarak kullanılan tanımlardan ve görüşlerden birkaç tanesini hatırlamak gerekirse; Laclau, ideolojiyi, devlet tanımlarından yola çıkarak, "toplumsal formasyonun birlik ve beraberliğini sağlayan ve devam ettiren, sistemin toplumsal koşullarını sürdüren ve yeniden üreten, devletle aynı amaca yönelmiş bir düzen" (Laclau, 1998, s.73) olarak nitelemiştir. Allard, "insan düşüncesinin ve eyleminin amacını, bu amaçlara nasıl varılacağını tanımlayan ve sosyal ve fiziki gerçeklerin niteliğini belirleyen bir değerlendirici prensipler sistemi" (Allard, 1971, s. 117) tanımını yapmıştır. Mardin ise (1976, s. 102-108) doğrudan bir ideoloji tanımı yapmak yerine, ideolojilerin toplumsal/ tarihsel/siyasal simgeleri aktarma, koruma, değiştirme işlevlerini kullanarak topluma yeni bir şekil ve anlam dünyası verme ve toplumsal düzenin aynı biçimde sürdürülmesi için dünya görüşünün korunmasını sağlama işlevlerini üstlendiklerini ifade etmiştir. Van Dijk'e göre ideolojilerin en önemli özelliklerinden biri kişisel olmamalarıdır. Yani doğal diller gibi, ideolojiler de bireyler tarafından kullanılan toplumsal durumlara karşıık gelmektedir. Başka bir deyişle, ideolojiler, sosyal olarak paylaşılan tüm inanç sistemlerinin ilk örneğidir. Böyle olunca Van Dijk' a göre ideolojiler, bir grup tarafından paylaşılan, kullanılabilecek temel norm ve değerleri içeren normsal inançlardır. Bu anlamda özgürlük, adalet, eşitlik vb. örnek olarak verilebilir. Dolayısıyla her sosyal grup tarafından kendi çıkarlarını dayatmak, savunmak veya mücadele etmek için kullanılırlar (Van Dijk, 2019).

İdeolojiye ilişkin yaklaşımlar bir arada düşünüldüğünde, Raymond Williams'a göre (1990, s. 48) ideolojinin geleneksel olarak üç temel kullanım tarzından bahsedilebilir. Söz konusu tarzlardan birincisi, belirli bir toplumsal sınıf ya da kesime özgü inançlar sistemi olmasıyla ilgilidir. İkincisi, genel manada "doğru" ya da bilimin nesnel dayanaklara sahip bilgileriyle çelişebilecek aldatıcı inançlar sistemi, yani yanlış düşünce ve kanaatler içermesidir. Üçüncüsü ise anlam ve düşünce üretiminin genel sürecini temsil ediyor olmasıdır. John Fiske, Williams'ın söz konusu 
kavramlaştırmaları üzerinde bir değerlendirme yaparak "birinci kullanım, sözcüğün psikologlar tarafından kullanımına daha yakındır" (Fiske, 1996, s. 212-214) tespitini dile getirmiştir. Williams'ın bahsettiği bu ilk kullanım biçiminde ideoloji sözcüğü, yalnızca iktidar tarafından üretilen değil, her bireyin edindiği tutumların tutarlılık zemini olarak kavramlaştırımaktadır. Fiske, ikinci kullanım biçimini ise, birincisiyle kaçınılmaz bir ilişki kuracak biçimde şöyle açıklamıştır (Fiske, 1996, s. 121, 124): "Böylece ideoloji, yönetici sınıfın işçi sınıfı üzerinde tahakkümünü sürdürmesini sağlayan yanılsamalar ve yanlış bilinç kategorisi hâline gelir. Yönetici sınıf, ideolojiyi aktaran ve toplum içinde yayan temel araçları kontrol ettiği için, işçi sınıfının kendi ikincil konumunu doğal ve dolayısıyla haklı görmesini sağlayabilir. Yanlışlık burada yatmaktadır. Bu ideolojik araçlar içinde eğitim sistemi, siyasal sistem, hukuk sistemi ve medya ile yayıncllı yer almaktadır". İdeolojinin bu anlamlandırlışbiçiminde Marx' ta temelinibulan ve Althusser'in "devletin ideolojik aygıtları" kategorilerinden yararlanılan bir kavramlaştırma söz konusudur. Bu anlamlandırma biçimi, ideolojinin "egemen ideoloji" olarak kavrandığına işaret etmektedir. Bu anlamalandırmada Antonio Gramsci'nin özel bir önemi vardır. Onun bu anlamlandırması, Althusser'in anlamlandırmasına temel olacaktır. Üçüncü anlamlandırma ise ilk iki anlamlandırmayı içerecek niteliktedir. Fiske bunu şöyle açıklamıştır: "ideoloji burada, anlamın toplumsal üretimini betimlemek için kullanılan bir terimdir. Bu şekilde kullanıldığında ideoloji, yan anlamların kaynağıdır. Mitler ve yan anlamlı değerler, ideoloji içinde kullanılabildikleri için var olurlar. İdeoloji, beni bilim temelli bałı kültürünün bir üyesi olarak inşa etmektedir, çünkü bu kültürün göstergelerini yan anlamlarını ve mitlerini uygun biçimde kullanabilmekteyim. Kültürümün anlamlandırma pratiklerine katılmakla, ideolojinin, kendini sürdürme araçlarından biri hâline geliyorum. İdeoloji, bu üçüncü kullanımda durağan bir değerler dizgesi ve görme yolları değil, bir pratiktir" (Fiske, 1996, s. 229).

İdeolojinin günümüzdeki anlamının inşasından önemli eşiklerden birisi olan Gramsci'ye göre 'iktidar', 'iletişim araçlarl' ve 'kitle' üçlüsünün birbirleriyle olan ilişkilerinde 'hegemonya'nın özel bir önemi vardır. Onun anlamlandırmasıyla hegemonya, ideolojiden daha geniş bir kategoridir: ideolojiyi kapsar, ama ona indirgenemez (Eagleton, 2005, s.165). Hegemonya, özetle 'rıa'nın üretilmesi demektir (Marshall, 1998, s. 299-300). Gramsci, hegemonyayı, kapitalist toplumlardaki sosyal düzeni korumanın başlıca aracı olarak görmüş ve özellikle yönetici sınıfın egemenliğini sürdürme araçlarına gönderme yapmıştır. Ona göre hegemonya, 


\section{arts}

bir sınıfın kendi "toplu" çıkarlarını savunmaktan, diğer bütün toplumsal grupları birleştirme ve yönlendirme konumuna geçmesini sağlayan politik, entelektüel ve ahlâki önderliğin bir sentezidir. Gramsci'nin kullanımındaki hegemonya "egemenlik" (hakimiyet)'ten de çok başka anlamdadır. Egemenlik, salt güce dayanan ve ideoloji, ahlâk, ortak değer gibi kavramlara yer bırakmayan bir zorlama ilişkisidir. Hegemonya ise, bir seçkin grubun dayatması değil, doğal grupların, bu seçkin grubun değerlerini ve önderliğini kabul etmesine ve bunun gereğine inanmalarına dayanmaktadır (Gramsci, 1997, s. 28).

Gramsci'nin ideolojiyi anlamaya yönelik kuramının orijinal yönlerinden birisi, "ideolojik gereçler" olarak isimlendirdiği yapı ile ilgilidir. Bu yapıyı, burjuvazinin kendi ideolojisini organize etme aygıtları oluşturmaktadır. Bu aygıtlar, Grammsci'de kitlesel eğitim, iletişim araçları, organik aydın şeklinde karşlık bulurken, Althusser'de ise devletin ideolojik araçları olarak karşıllık bulacaktır. Bunların en önemlisi ise kitle iletişim araçlarıdır. Aynı zamanda kütüphanelerden okullara, şehir mimarisinden müzelere kadar birçok alan bu yapının içinde yer alır (Hall ve Jacques, 1979: 315318). Gramsci'nin özellikle hegemonya ile ilgili görüşleri kitle iletişim araçlarına uygulandığında şu anlama gelmektedir (Yaylagül, 2014, s.114): Kitle iletişim araçları okuyuculara-dinleyicilere-izleyicilere egemen sınıfın değerlerini aktaran araçlardır. Bunlar Kapitalist düzeni normal kabul ederler. Bireyciliği yüceltirler. Kitle iletişim araçları, egemen yapıya ve anlayışa muhalif olan her yapı ve anlayışa muhaliftirler. Bu sebeple işçi sınıfına ve onun ideolojisine yakın veya yakın olma ihtimali taşıyan sendikalar, eylemciler, çevreciler kitle iletim araçlarının karşı olduğu kesimleri oluştururlar.

İdeolojinin anlam alanının oluşumunda önemli eşiklerden bir diğeri Althusser' dir. Althusser açısından ideoloji, iktidar-iletişim araçları-kitle ilişkisinin temel tanımlayanı ve açıklayanıdır. İdeolojiyi "toplumun çoğunluğunca paylaşılması bakımından bir anlamda nesnel, ama aslında o toplumun genel bakış açısının dışındaki gerçekliğe varamayan bilgi çeşidi" (2004a, s.19) olarak tanımlayan Althusser'e göre ideoloji, işlevsel açıdan en genel açıdan, toplumsal bütünlüğü ve işleyişi yeniden üretim sürecinde siyasal ve ekonomik iktidarın kullandığı ikna yöntemini sağlayan önemli bir araçtır. Daha da önemlisi ideoloji, her yana yayılmış pratikler olarak insanların tüm etkinliklerinin içine sızabilen bir şeydir (Althusser, 2004b, s. 104). Bu yönüyle toplumsal 
bütünlüğün organik bir parçasıdır.

Althusser, egemen ideolojinin sürekliliğinde ve toplumsallığın yeniden üretiminde gerekli olduğunu ifade ettiği ideoloji görüşünde Platon'un "soylu yalan" (Althusser, 2003, s. 87) ve Marx'ın "Camera Obscura" (Marx ve Engels, 2004, s. 45, 216) kavramlaştırmalarını kendisine başlangıç noktası olarak almıştır. Ancak söz konusu kavramlaştırmaları fazlasıyla aşan ve kendi içinde son derece sistematik ve bütünselliği olan bir kuram geliştirmiştir. Althusser, özellikle Devletin İdeolojik Aygıtları eserinde Marx'ın 'yanlış bilinç' görüşünden tamamıyla uzaklaştırdığı, çok daha kapsamlı bir kuram olarak ortaya çıkardığı ideolojiyi, bireysel özneler düzleminde ve onların gündelik ilişkilerinde belirleyici, tutum ve davranışlarında işlevsel bir referans olarak ortaya koymuştur. İdeolojiyi, yaşayan somut bireyleri iş bölümü çerçevesinde, üretim-sömürü-baskı-ideolojikleştirme faktörlerinin farklı evrelerinde, kendi başlarına davranabilen ve başlarına birer zabıta dikmeden bunu başarmalarına olanak veren bir referans olarak nitelemiştir.

Althusser'e göre, Devletin İdeolojik Aygıtları'nda detaylı olarak ele aldığı üzere, ideoloji, üretim ilişkilerinin yeniden üretimini sağlayan sistemin ismi olup, bunun somutlaştığı yapı ise 'iktidarın ideolojik aygıtları' ve 'baskı aygıtları' olarak vücut bulmaktadır. İktidarın ideolojik aygıtları, ideoloji çerçevesinde bireyin özne olarak kurulmasına yardım ederlerken, ideolojiyi somutlaştıır ve ona maddi var oluş kazandırılar. Althusser'e göre devletin (iktidarın) birden çok ideolojik aygıtı vardır. Bunlar görünüşte dağınık olmakla birlikte, büyük ölçüde özel alanda toplanmışlardır. Fakat özel ya da kamusal alanda bulunmaları önemli değildir; önemli olan işleyişleridir. Söz konusu ideolojik aygıtları 'din', 'eğitim', 'aile', 'siyaset', 'hukuk', 'sendika', 'kültür' ve 'iletişim araçları' teşkil etmektedir. Bu çeşitliliği işleyiş bakımından birleştiren şey ise 'egemen ideoloji' dir. 'Ideolojik aygıtlar' ile 'baskı aygıtları' arasındaki temel fark ise, baskı aygıtlarının zor kullanarak işlemesi, ideolojik aygıtların ise ideoloji kullanarak işlemesidir. Althusser'e göre kitle iletişim araçları, egemen ideolojiyi yurttaşlara taşınmasının temel aracıdırlar (Althusser, 2003, s.171). Fakat salt ideolojik aygıt yoktur. Bu sebeple ideolojiye ağırlık vererek işlemeleri, kitle iletişim araçlarının gizli ya da hafifletilmiş anlamda baskı unsurları içermediğini göstermez. Hatta etkileri devletin baskı aygıtından bile daha güçlüdür. Kapitalizm öncesi dönemde kilise, yalnızca dinsel işlevi değil, haberleşme, kültür, eğitim ve öğretim işlevleri de yerine 


\section{arts}

getirmekteydi. Günümüzde ileri kapitalist toplumlarda kitle iletişim araçları tartışmasız bir öneme sahiptir. İktidar, toplumun rızasını sağlayarak toplumsal yeniden üretim yapmayı ve hegemonyayı, devletin ideolojik aygıtlarını kullanarak sağlamaktadır. Kitle iletişim araçları ise bu bağlamda önemli işlevler üstlenmişlerdir (Althusser, 2003, s.170- 185).

İdeoloji sözcüğünün bu kadar farklı, değişken ve çok anlamlı olmasının nedenlerine ilişkin açıklamalar da yapılmıştır. Bunlardan birisi ve en bilineni Foucault'ya aittir. Ona göre bu farkllık ve değişkenliğin temel nedeni ideolojinin yorumlara açık niteliğinden kaynaklanmaktadır. Bu özelliği nedeniyle ideoloji, farkı bireylere, toplum kesimlerine yahut düşünürlere göre farklı anlamlar kazanarak anlam ve işlev değişimine uğramakta ve birbirinden oldukça farklı özellikleriyle konu edinilmektedir. Bu arada Foucault da kendi tanımını vermiş ve ideolojinin hakikat karşısında 'sahte olanı', daha doğrusu 'kurgusal olanı' temsil ettiğini dile getirmiştir (Purvis ve Hunt, 2014). Foucault'ya göre iktidar, gücü elinde tutan belli bir toplumsal sınıfın güdümünde değildir, toplumun bütün dokularına işlemiştir, gündelik yaşam pratiklerinin içinde, söylemdedir. İnsanlar iktidarla kuşatıldıklarının ve onun yeniden üretiminde bizzat rol aldıklarının farkında olmaksızın bu işleyişe katılırlar (Güngör, 2011, s.55).

Buradaki örneklerden de kolaylıkla anlaşılacağı üzere, ideolojinin anlam ve işlevine ilişkin dile getirilen ilk tespitlerden birisi, ideolojinin tüm sosyal bilimlerde geçerli standart bir tanımının bulunmuyor olmasıdır. Kişiler veya spesifik uğraş alanları bağlamında kolaylıkla tanımlanıyor olmasına rağmen, genel ve herkes tarafından kabul edilen bir tanımı yapılamamıştır. Andrew Heywood'a göre bunun iki temel sebebi bulunmaktadır. Birincisi, ideoloji teori ile uygulama arasında bir bağın varlığını kabul ettiğinden; bir taraftan, siyasette fikirlerin rolünü ve inançlarla kuramlar arasındaki ilişkiyi, diğer taraftan da maddi yaşam ve siyasi tutumları dile getirmektedir. İkinci olarak, genel olarak ideoloji, kendini siyasi ideolojiler arasında süre giden mücadelenin dışında tutamamıştır. İdeoloji sözcüğü tarihsel macerasının çoğunda rakip fikir ya da inanç sistemlerine saldırı silahı veya aracı olarak kullanılmışıır. 20. yüzyılın ikinci yarısına kadar, tarafsız ve nesnelliği açık olarak ifade edilmiş bir ideoloji anlayışı yaygın bir şekilde kullanılmamışıı (Heywood, 2007, s. 7). Tüm bunlar dikkate alındığında ideoloji için söylenmiş ve söylenebilecek tespit ve 
görüşlerden en bilinenleri olarak şunlar ifade edilebilir: "1. Siyasi bir inanç sistemi; 2. Eylem yönelimli siyasi fikirler kümesi; 3. Yönetici sınıfın fikirleri; 4. Belli bir sosyal sınıf veya sosyal grubun dünya görüşü; 5. Sınıfsal veya sosyal çıkarları dışarı vuran siyasi fikirler; 6. Sömürülenler veya baskı altındakiler arasında yanlış bilinci yayan fikirler; 7. Bireyi sosyal bir bağlamda konumlandıran ve müşterek aidiyet hissi yaratan fikirler; 8. Bir siyasi sistemi veya rejimi meşrulaştırmak üzere, resmi olarak ayrıcalık verilmiş fikirler kümesi; 9. Hakikat tekeli iddiasındaki her şeyi kapsayan siyasi öğreti; 10. Soyut ve oldukça sistematik nitelikteki siyasi idealler kümesi" (Heywood, 2007, s. 7). Bu özet bilgi ise ideolojinin, oluşum ve gelişim sürecinde üstlendiği anlamsal ve işlevsel boyutları işaret etmektedir.

\section{İdeolojinin Doğuşu}

İdeoloji, Latince 'idea' (düşünce) ve 'logy' (bilim) sözcüklerinin birleştirilmesinden üretilmiş modern zamanlara özgü bir sözcüktür. İlk defa 1796 ylında Fransız devrimi sürecinde kullanıldı. Bir sözlükte ilk kez madde başı olması ise Fransız Akademi Sözlüğü'nün 1835'teki üçüncü basımında gerçekleşti. Söz konusu sözlükte "düşünceler ilmi", "düşüncelerin kaynağı ve kuruluşu hakkında sistem" (Meriç, 1970, s. 119) olarak tanımlanan ideoloji sözcüğünü ilk kez telaffuz eden kişi Fransız ideolog Destutt de Tracy'dir. Tracy bu sözcüğü, kendi düşünce sistemi bağlamında yeniden dizayn ettiği oldukça köklü bir geleneğe sahip bilgi, bilim, tanrı-din, siyaset, toplumsal kabuller ile ilgili düşünce, inanç ve felsefelerin bütüne isim olarak vermiştir. Fakat içinde bulunduğu zaman ve toplum itibarıla yalnız değildir. Paris'teki Institut de France'da 1796-1798 yılları arasında Mémoire sur la Faculté de Penseé ismi altında bildiriler kaleme alan ve kendilerini 'ideologlar' olarak niteleyen aydınlar grubunun önemli temsilcilerinden birisidir. Bu grubun amacı 'devrimin vadettiği söz ve düşünce özgürlüğünü pratikte gerçekleştirmenin' yöntemini belirlemekti. Kendilerini nitelemede kullandıkları ideologlar ismini de bu kapsamda anlamlandırıp, benimsediler. Stuart Hall'ün dikkate çektiği üzere, misyonlarını nitelemek için ürettikleri ideoloji sözcüğünün anlamıyla ilgili olarak hep var olan bir ikilem içine düşmekten ide bir türlü kendilerini kurtaramadılar. İdeolojiyi, mantıki olarak birbiriyle tamamen örtüşmeyen iki farklı alanı ifade için tercih ettiler. Bu, tarih-düşünce veya devrimdüşünce arasındaki bağ ile ilgili bir durumdu. Fakat bu arada kendilerince kalıcı, değişmeyen düşünce ölçütleri de geliştirmek istiyorlardı. İçinde bulundukları tarihsel konjonktür ne olursa olsun, doğru olacak düşünceler belirlemek amacındaydılar 


\section{$\operatorname{arts}=$}

(Hall, 2014, s. 70).

İdeoloji sözcüğünü ilk kez Tracy kullanmış olmakla birlikte, doğuşunu takip eden birkaç on yıl içinde tanınıp yaygınlaşmasında Napoleon Bonapart'tan Thomas Jefferson (1743-1826)'a kadar birçok aydın ve devlet adamının önemli katkısı vardır. İdeoloji isim olarak Fransa'da doğmuş ama yaygın kullanımının ilk aşaması Amerika'da gerçekleşmiştir. Destutt de Tracy ile mektuplaşan Thomas Jefferson, ideoloji sözcüğünün Amerika'daki serüveninin başlatıcısıdır. Kullanımlarıyla ideolojiyi uzun süre gündemde tutmayı başaran Ídeologlar ise kitaplarıyla ideoloji sözcüğünün ve bu sözcükte karşılık bulan döneme ait anlamın Fransa dışındaki felsefe tartışmalarında yaygın olarak kullanılmasına önemli katkılar sağladılar.

Tracy ve arkadaşlarının kullanımında olumlu anlama sahip olan ideoloji, kısa süre sonra olumsuz anlama sahip bir sözcük olarak kullanılmaya başlandı. Bu değişimin aktörü Napoleon Bonapart (1769-1821)'tır. Napoleon Bonapart, Fransız devrimi yıllarında ideoloji sözcüğünü türeten İdeologlar'ın ilk ve önemli temsilcilerinden birisiydi. Fakat bir süre sonra Ideologlar'dan ayrıldı. Bu ayrıışı, bir topluluktan ayrımanın ötesine taşındı. İdeologlar tarafından olumlu ve işlevsel manada kullanılan ideoloji sözcüğüne olumsuz bir anlam yükledi. Değişimin temelinde kendisinin kariyer yolculuğunda gerçekleşen değişimler vardır. 1799 yılına kadar ideologlar topluluğuna dahil olan ve bununla övünç duyan Napoleon, iktidarı ele geçirip kendi mutlakiyetçi amaçları doğrultusunda hareket etmeye başlayınca ideologlar ile fikren ve fiilen çatışmaya girdi. Öyle ki "Güzel Fransa' mızın başına gelen her türlü musibeti ideologların öğretisine... şu karman çorman metafiziğe yormak gerekir" (Williams, 2007, s.185) demeye başladı. Bonaparte' a göre eski arkadaşları ve fikirdaşları olan İdeologlar, siyasi zekâları kıt, sadece zihinleriyle dünyayı değiştirmeyi arzulayan metafizikçilerdi. Ona göre İdeologlar, iyi bir toplum modelini insanlara kabul ettirmeye çalışmaktan başka bir şey yapmamaktadırlar. Fakat bunu yaparken bu fikirler dizisinin gerçeklikle uyuşup uyuşmadığını bir tarafa bırakıp spekülasyonlarla uğraşmaktalar. Napoleon, eleştiri ve hakaretlerinde daha da ileri giderek 1801 'de Ideologları siyasi otoriteyi çökertmeye çalışan 'gevezeler' olarak suçladı. 1802 Kilise Devlet Antlaşması ile konumunu iyiden yiye sağlamlaştırınca ideologları "ateisł" olmakla suçladı. İdeoloji sözcüğünün, entelektüel verimsizliği, pratik yeteneksizliği ve özellikle de tehlikeli siyasal fikirleri içeren bu yeni anlamı kısa zamanda yaygın bir 
kabul buldu. Tracy' nin konuya ilişkin kitabının 1829' da yeniden basılmasından sonra da iyice yaygınlaşıı (Bulut, 2011 , s.187). Tüm bunlar, ideolojinin zamanla kazanacağı olumlu-olumsuz anlam spektrumunun daha doğuş aşamasında şekillenmeye başladığını göstermesi açısından oldukça önemlidir.

\section{İdeolojinin Kavramsal Öncüleri}

Destutt de Tracy'nin 1796' da yaptığı şey, Auguste Comte'un toplumun bilimi için 'sosyoloji' ismini belirlemesinde olduğu gibi, düşünceler ve olgular bağlamında Özel bir anlamlandırma ve değerlendirme tarzına 'ideoloji' ismini seçmiş olmasından ibarettir. Elbette ki 'ideoloji' olarak isimlendirdiği ve 'düşünce bilimi' olarak nitelediği şeye ilişkin görüşler dile getirmekten de geri durmadı. Iffade ettiği görüş ve tespitlerin ise birçok bakımdan öncüsü değildir. Çünkü, öncesinde her ne kadar 'ideoloji' sözcüğü icat edilmemiş olsa bile, daha sonra 'ideoloji' ile kastedilen anlamları çağrıştıran ve hatta ifade eden sözcük ve düşüncelerin var olduğunu; tarihsel süreçte konu bağlamında oldukça kapsamlı bir literatür oluştuğunu biliyoruz (Çelik, 2005, s. 28, 29). Dolayısıyla eğer ideolojinin sözcük tarihi değil de anlamsal (kavramsal) geçmişi dikkate alınacak ise ilk bahsedilecek isimlerden birisi hiç kuşkusuz Platon (427347)'dur. Ayrıca Francis Bacon (1561-1626), Étienne Bonnot de Condillac (1715-1780) ve Claude Adrien Helvétius (1715-1771)'un isimleri de oldukça önemlidir. Tracy'nin bizzał kendisi Condillac'ı ideoloji sözcüğünün kavramsal öncüsü olarak anmış olması ise anlamlıdır Tracy, 1956).

Platon'un ideoloji bağlamında değerlendirilebilecek görüşleri 'soylu yalan' sözcüğü ile ifade ettiği düşüncelerde yer almaktadır. Platon da tüm diğer filozoflar gibi 'gerçek' arayıcısıdır. Ona göre de 'yalan' 'gerçek' olan ile çelişir. Dolayısıyla ahlaklı birisinin gerçek olana ilişkin yalan söylemesi kabul edilemez. Ahlakı birisinin gerçek olan ile ilgili yalan söylemesi, ancak gerçeği unuttuğu, gerçeğin aleyhine büyülendiği ya da gerçek olandan uzaklaşması için zorlandığı koşullarda söz konusu olabilir. Bu durumlarda söylediklerinin ise bir değeri yoktur. Zira bu durumlarda ifade edilen şeyler gerçek değildir.

Platon' a göre 'yalan' olan şey yanlış, kötü ve zararlıdır; siyasal boyutuyla ifade etmek gerekirse 'devlet'i batırır (Platon, 2005, s. 214). Bu nedenle yalan kesinlikle kaçınılması gereken bir zehirdir. Fakat Platon, tüm zehirler için geçerli olduğu gibi, 


\section{arts}

yalanın da yerinde kullanılığında bir ilaç işlevi görebileceğini düşünmüştür (Platon, 2005, s. 213). Bu da Platon'un yalandan ayırarak 'soylu yalan' dediği bir başka yalan türüne işaret etmektedir. Bu yalan türü ancak gerçek olanı desteklediği ve insanları başka yanlışlardan koruduğu kullanımlarda yarar sağlayabilir. Fakat böylesi bir kullanım hiçbir şekilde sıradan bir insandan beklenemez. Normal şatlarda öldürücü olan zehrin ancak bir hekim elinde şifaya dönüştüğü gibi, yalan da ancak yönetici, yani filozofun elinde yararlı olabilir (Platon, 2005, s. 362). Soylu yalanın başlıca işlevi, insanları yanlışlardan uzak tutarak, bir düzenin kurulmasını ve/ya da korunmasını sağlamaktır. Soylu yalan, bir yalan türü olmakla birlikte, gerçeklik hakkında söylenen yalanlardan tamamen farklıdır. Her soylu yalan bir gerçeği önceler. Örneğin bireylerin ontolojik yanılgılarının ürünü olan 'insanların birbirlerine denk/eşit oldukları' gibi bir fikre kapılmalarını önlemek, soylu yalan sayesinde mümkün olabilir. Böylece başka cevaplar arama ve muhtemel yanılgılara kapılma ihtimali büyük ölçüde önlenmiş olur. Bireyler soylu yalanı kabullenirler ve onun yönlendirmesiyle hareket ederler. Bu toplumsal yaşamın gereğidir. Zira ancak böylece ya istenilen bir düzenin kurulması için temel oluşturulur ya da düzenin korunması sağlanır. Soylu yalan, toplumsal yaşamda temel olan adalet düşünce ve uygulamaları için zorunludur. Çünkü düzenin korunması adalet ile gerçekleşebilir ve adaletin varlığı soylu yalan ile mümkün olabilir (Platon, 2005).

'Soylu yalan' olarak nitelediği ve gerçek olan ile çelişen düşünce ve görüşleri toplumsal yaşam ve sistem için 'gerekli' bulan Platon'a karşılık, Francis Bacon ise gerçeğe ulaşabilmek için düşünceyi engelleyen genel ve özel kabullerden uzaklaşmayı zorunlu bulur. Söz konusu engelleri 'idol' sözcüğü ile tanımlamıştır. Bacon' a göre gerçekliğe ulaşmanın yalnız iki yolu vardır. Bunlardan ilki "algılarımızı bir yana itip, aradığımız doğruları dedüktif çıkarımla elde edeceğimiz doğruluğu apaçık aksiyomlar bulmaktır. İincisi, tam tersine, olguların tek tek gözleminden başlayıp genellemelere gitmek, bu genellemelerden daha genel aksiyomlara ulaşmaktır" (Yıldırım, 1985, s. 68). Bacon'un birinci yolu yararsız, ikinci yolu ise doğru ve yararlı olarak nitelemiştir. Bununla Bacon tümdengelime bilimsel bir ideal olarak karşı çıkıp, tümdengelimini bilimsel yöntemin temeli yapmak istemiştir. Bacon yönteme ilişkin görüşlerinde gerçeği görmeyi engellediğini iddia ettiği dört idolden bahsetmiştir:

1. Idola tribus (Kabile idolleri): Bütün insanlarda görülen, olan bitenleri başka 


\section{$\operatorname{arts}=$}

türlü görmemize neden olan idollerdir. Eşitlik, uğraşı, ihtiras gibi tipleri vardır ve işimize yaradığı şekilde doğru saymamıza ve kendi hesabımıza göre kullanan duygu ve ihtiraslarımızın konularını gerçekleşmiş gibi görmemize yol açarlar.

2. Idola specus (Mağara idolleri): Sosyalleşme sürecinde benimsenen idollerdir. Sosyalleşme sürecinde toplumun değer ve yaşam ölçütleri benimsendiğine göre, mağara idolü "kültür" ile karşılanabilir.

3. Idola fori (Çarşı idolleri): Kavramları şeylerin yerine koymaktır; kavramlar arasında değiş tokuş yaparak gerçeklikten uzaklaşmaktır

4. Idola theatri (Tiyatro idolleri): Düşünce, görüş, kanaat gibi gerçekten uzak veya gerçeği tahrip eden şeyler.

Bacon'a göre bu idoller gerçeği arayanlar ile gerçek arasına girerek, gerçeği ulaşmayı önlemektedir. Bu nedenle gerçeğe ulaşabilmenin temel şartı bu tür idollerden sıyrılmaktır.

İdeolojinin oluşumunda önemli tarihsel duraklardan birisi Aydınlanma çağı ve bu çağın özellikle de bazı aydınlarıdır. Bunlar arasında Condillac ve Helvétius özel bir öneme sahiptir. Her ikisi de isim vermeden ideolojiden bahsetmişlerdir. Her ikisine göre sonradan ideoloji olarak isimlendirilecek kabullerin güçlü olanın diğerlerini egemenliği altında tutmasını sağlayan düşünceler olduğunu ifade etmişlerdir.

Étienne Bonnot de Condillac'a göre (1989; 1992), neredeyse tüm insanlar arasında genel bir kabule dönüşmüş olan dünyanın algılanmasında insanın sahip olduğu ruhsal durumun etkili olduğu, insanın ruhsal durumuna göre dünyayı irdeleyip, yargılarını dile getirdiği (bilgiye ulaştığı) görüşü tamamıyla yanlıştır. Hatta doğru olan bunun tam tersidir. Condillac'a göre bilgi, objenin (bilinen) süje (bilen) üzerinde bıraktığı bir izdir; dış dünyadaki nesnelerin duyumlar üzerindeki etkilerinin zihindeki izlenimleridir. Duyular ise bu sürecin temel araçlarıdır. Fakat duyumlar da tek başına bilgi inşa edemezler. Zihin devrede olmak zorundadır. Ancak zihinde duyu verileri olmadan düşünemez, zira böyle bir şey düşünmemek olur. Zihin duyulardan gelen verileri anlamlandırmada deneyimler ve duyguya dönüştürür. Dolayısıyla bilgi doğuştan gelen bir şey değil, kazanılan bir şeydir. Condillac, zihnin boş bir levha olduğu konusunda Locke (1632-1704) gibi düşünür. Ona göre zihin; en alışımış ve 


\section{arts}

belli fikirlerin dışında fikirler edinilmesini sağlayan araçtır. Bu nedenle her insanın fikirleri farklıdır. Locke'a göre insan zihni doğduğu anda düz beyaz bir kâğıt gibidir. Ruhumuzda sadece bazı yetilerimiz vardır. Fakat bu düz levhaya izlerini bırakan, fikirlerin oluşumunda araya giren ruhun faaliyetini reddetmek suretiyle Locke'tan ayrıır. Condillac, fikirlerimizin sadece duyumlardan doğduğunu iddia eder. Yine ona göre düşüncenin kendisi de duyumların dönüşümünden başka bir şey değildir. Bu ise insanın yaşadığı koşulların onun düşüncesini şekillendirdiği anlamına gelmektedir. Dil ise bu bağlamda son derece önemlidir.

Condillac bilginin oluşumunda dilin de önemine bilhassa dikkat çekmiştir. Ona göre bilgilerimizi teorik ve pratik bilgiler olmak üzere ikiye ayırabiliriz. Bizi bir dil kullanmaya muhtaç eden ise kuramsal bilgilerdir. Kuramsal bilgilerimiz bir sürü seçik fikirlere dayanır ve bunları sınıfandırmak ve belirlemek için birtakım işaretlere intiyaç duyulmuştur. Ona göre dil, bilgimizi sistematikleştiren simgeler sistemidir. Bu sistem ne kadar rasyonel çalışırsa dışarıdan gelen girdiler, etkiler o kadar doğru algılanır. Condillac bu aşamada önemli bir tespitte bulunarak, dilde veya kullanılışında bir pürüz olduğunda gerçeklerin yanlı olarak algılanacağını ifade eder. Dolayısıyla hakikatlere varabilmek ve onları pürüzsüz olarak algılamak için dil üzerinden rasyonel bağlar kurmak gerekmektedir (Mardin, 2006, s. 22-23). Dönemsel bağlamıyla ifade etmek gerekirse, doğru düşünmenin yolu olan ideoloji, Condillac'a göre, yansız ve doğru kullanımına bağlıdır. Yani içten bir biçimlendiriciye değil, dıştan bir etkene intiyaç vardır.

Bilgi ve bilginin oluşumunda dış dünyanın rolü konularında dikkat çeken tespitleri bulunan ve ideolojinin inşasında önemli rol üstlenenlerden bir diğeri Helvétius'tur. Zamanın Voltaire, d'Alembert, Rousseau gibi filozoflarının aksine John Locke'un doğuştan geldiği (verili olduğu) savunulan düşüncelere ilişkin eleştirilerini takip ederek, insanların doğduklarında tamamıyla birer 'tabula rasa' durumunda olduklarını iddia eden Helvetius, insanın kişilik oluşumunda topplumsal ve fiziksel çevresinin belirleyici faktör olduğunun altını kalınca çizmiş ve duyumsal tecrübelerin bilgiye elde etmedeki işlevi üzerinde durmuştur. Helvétius'a göre, aynen Condillac'da olduğu üzere, insan zihninin oluşumunda dıştan gelen veriler belirleyicidir. Bu bakımdan insan duygu ve düşünceleri ile çevrenin ürünüdür; zihin dünyası içinde bulunduğu şartlar tarafından şekillendirilir. Örneğin bir insandaki ahlaki 
düzeyi ve düşünme kudretini oluşturan eğitim sistemidir. Ona göre "bizi biz yapan şey eğitimdir", "yalnızca bildiğimiz değil, olduğumuz şey, bir insan; duygularıyla, zekasıyla, ahlaklılığıyla bir insan yapar" (Reboul, 1991, s. 25-26). Ona göre eğitim sistemini belirleyip uygulamaya koyan takiben gözetleyen devletin politikasıdır (Mardin, 2006, s. 23). Böyle olunca devletin kontrolü altındaki sistemin değişmesi durumunda, sonuçlar da değişir. Helvetius, yaptığı bu vurgu ile Condillac'ın teorisini daha ileri götürmüş ve güçlendirmiştir.

\section{Aydınlanma Çağı ve İdeoloji}

İdeoloji, 14. yüzyılda hümanist çalışmalarla başlayıp Aydınlanma ile kapsamlı sistematiğine kavuşan sürecin eksenindeki din-bilim çatışmasının ve özellikle de toplumsal ve hatta bireysel yaşamın tüm alanlarında dini etkisizleştirme çabalarının ürünü olarak doğmuştur. Dört yüz yıllık söz konusu süreç insanın, eşyanın, dünyanın yeniden tanımlanmasını temsil etmektedir. Bu süreç, 'kilise' ve dolayısıyla 'din', daha da önemlisi 'tanrı' referanslı insan, eşya ve dünya anlayışından insan referanslı insan, eşya ve dünya anlayışına geçişin inşa edildiği bir zaman dilimi olarak anlam kazanmaktadır. Hümanizm ise bir felsefe olarak bu süreçte temeli teşkil etmiştir. Zira, hümanizm her şeyin ölçüsü olarak insanı kabul eden felsefedir. Aşkın olana gözlerini kapayıp, sadece içkin olana yönelen bir anlayıştır. Hümanizm ve onun bağlamında oluşan seküler zihniyet, kilisenin skolastik Orta Çağ anlayışını reddederek bilimde, felsefede, sanat ve edebiyatta tamamıyla 'özgür' insan anlayışını savunmuştur. İnsanın bu özgürlüğü Kilise, Din ve Tanrı karşııında anlam kazanan, onlardan kopuşu dile getiren bir özgürlüktür (Paine, 2012, s. 4). Dolayısıyla İnsan her alanda yüceltilmiş; onun üstünde bir değer ve irade kabul görmemiştir. Böylelikle ortaya laik, seküler, akılcı ve yaşama her şeyden fazla değer veren 'rasyonel birey' çıkmıştır. Bundan böyle insanın, başka herhangi bir referansa ihtiyaç hissetmeden hayatını tamamıyla kendi aklıyla düzenleyebileceği öngörülmüştür (Gökberk, 1974, s. 336, 337). Erken dönem modern düşüncenin oluşum sürecini araştırmış olan Paul Hazard'ın, gerçekleşenleri özetleyen tespiti son derece önemli ve anlamlıdır: "Tanrı semada bir yerde, bilinmeyen ve nüfuz edilemeyen bir gökte bırakıldı. İnsan, sadece ve sadece insan, her şeyin ölçüsü oldu. İnsanın hikmeti vücudu yine kendisi idi" (Hazard, 1981, s. 18). 


\section{$\operatorname{arts}=$}

Nitekim bu büyük değişimi/dönüşümü şekillendiren, özellikle evrensel otoritelerin nüfuzlarını kaybetmelerinde birinci derecede etkili olan temel unsur, Orta Çağ'ın tanrı merkezli dinsel düzeninin yerini, Aydınlanmadan sonra insan merkezli rasyonel düzenlerin alması olmuştur (Taylor, 2009, s. 50). Bir tarafta Papa ve Imparatorluğun etkisinden uzak İtalyan kentlerinde Poppoli Grossi denilen yeni yeni patronlar ortaya çıkmış, diğer tarafta keşifler sonrasında Amerika'dan gelen zenginliklerin biriktirilmesiyle merkantilizm doğmuş, ticaret yeniden şekillenmiş, burjuvazi oluşmuştur. Bu yeni sınıfların ticari kazançlarını daha da artırmak için destek vermeleriyle bilimsel çalışmalar baş döndürücü bir gelişme içine girerken, Anglikanizm, Calvinizm, Cizvitizm, Ortodoksluk ve Protestanlık ve Prütenlik gibi ulusal mezhepler ortaya çıkmış, bu arada Kutsal Kitap önce Latince'den ulusal dillere çevrilmiş, ardından matbaayla tüm Avrupa'ya dağıtılmıs, sonuçta, asırlardır uygulanagelen aforoz, enterdi, endülüjans gibi yaptıımların aslında olmadığı ortaya çıkmış ve Kiliseye olan inanç kökten sarsılmıştır. Bu süreçte Kilise önemini ve etkinliğini yitirirken, insanın kendisine ve aklına olan inanç yükselişe geçmiştir. Ne yapılırsa yapısın dünyanın gizemlerinin çözülemeyeceği ve kanunlarının değişsirilemeyeceği pasif düşüncesinden, var olan her şeye egemen olunabileceği aktif düşüncesine bir yöneliş başlamıştır. Artık tüm toplumsal çözümlemelerin merkezinde insan vardır ve Hümanizm dalga dalga yaylıp Kilisenin karsısında yepyeni bir evrensel kimlik olarak yerini almıştır (Budak, 2007).

Sürecin en yoğun ve sistematize olduğu dönem Aydınlanma Çağı olarak isimlendirilen dönemdir. Bu nedenle 'Aydınlanma'yı irdelemek yararlı olacaktır. Aydınlanma, çokça tanımlanmış ve özellikleri konusunda sayısız denecek kadar çok kitap ve makale yazılmış bir olgudur. Yapılmış çok sayıda açıklama ve tanımlara örnek olarak öncelikle Kant dikkate alınabilir. Kant, 'Aydınlanma Nedir' ismini taşıyan hacim olarak küçük ama niteliğiyle büyük ünlü eserinde Aydınlanmaya ilişkin tespiti oldukça önemli bir tespit ve yol gösterici bir rehberlik çabası olarak anlam kazanmıştır:

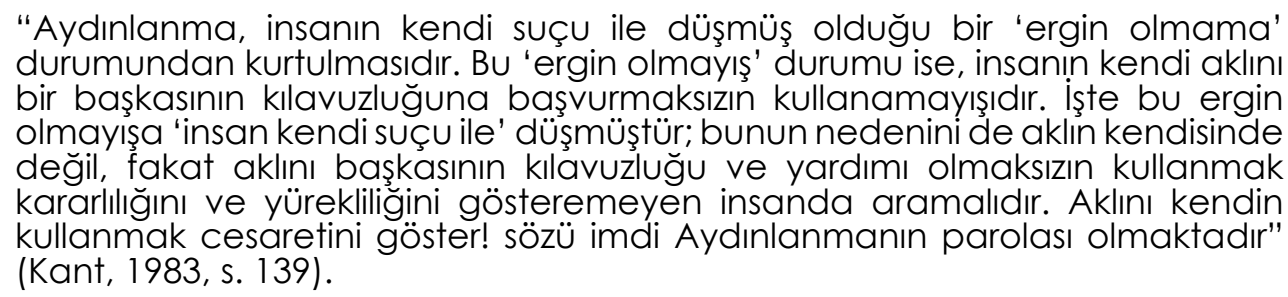

Ayrıca, Aydınlanmaya ilişkin güncel bir örnek olarak Edelman'ın tanımı 
dikkate alınabilir. Edelman'a göre Aydınlanma "geleneksel kozmolojik, antropolojik ve teolojik [referansı] kültürel sentezlerin parçalanmasının ardından Orta Çağ'ın sonlarında başlayan yeni bir kültürel sentez arayışıdır" (Edelman, 2004, s. 1). Çiğdem'e göre ise Aydınlanma, insanlık tarihinde akıl ve düşüncenin bireyin en güçlü yetisi olarak birleşmiş bir biçimde, dünyanın ve toplumun metafizik ve mistifiye edilmiş anlaşıımasına dayalı geleneksel toplum ve bilgi yapılarının ortadan kaldırmasını ifade etmektedir (Çiğdem, 1997, s. 21). Yine Çiğdem, Aydınlanmadan ne anlaşılabileceğini şu ifadelerle dile getirmiştir:

\begin{abstract}
"Aydınlanma deyince 18. yüzyılda, gerçekleşmesi ve sonuçları itibariyle hem Amerika hem de hemen hemen Avrupa'nın her tarafında etkili olan, geleneksel olarak Ingiliz Devrimi'yle başlatılıp, Fransız Devrimiyle bitirilen felsefi bir hareket ve daha da önemlisi, bu hareketin sonuçlarıyla belirginlik kazanan toplumsal ve siyasal bir sürece göndermede bulunuyoruz" (Çiğdem, 1997, s. 13).
\end{abstract}

Marshall'ın Aydınlanma'dan anladığı da bu bağlamda manidar bir yere oturmaktadır:

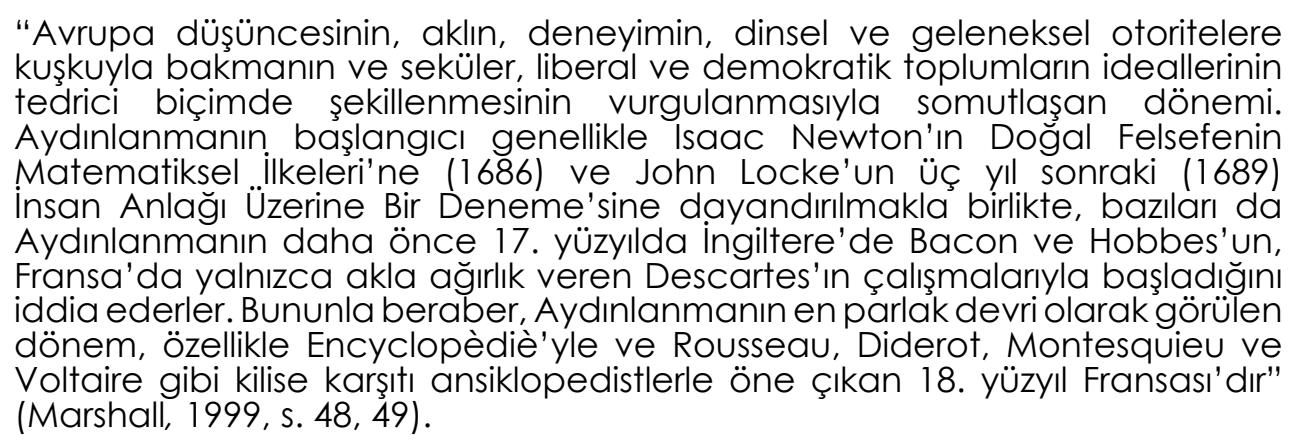

Akıl bağlamında ifade etmek gerekirse, Aydınlanma, insanlığı, eleştirel aklın kullanılmasıyla dinden, mitten, batıl inançtan, gizemli güçlere ve doğa güçlerine tabi olmaktan kurtarma idealine dayanmıştır. Bu sayede insanın dünyadaki konumu, emek ve eğlence tarzı artık bir dışşal/aşkın otoriteye değil, fakat kendi özgür rasyonel etkinliğine dayalı bir hale geleceği savunulmuştur. Aydınlanma felsefesini, kendisinin hemen öncesinde yer alan felsefeden ayıran, yalnızca birkaç kişinin alanı olan bir şeyi, yani akla uygun olarak yürütülen düşünme ve hayat tarzını herkese uygulama iddiasıdır. Batı dünyasının bu yeni akılcıı̆ğı, 'dünyayı eski anlam düzeninden koparmış'; akılcı bir bakış altından değerlerden, idelerden arınmış bir dünya ise, artık 'büyüsünü yitirmiş bir dünya' haline gelmiştir (Özlem, 1990, s. 58). Hampson'ın ifadeleriyle;

"Aydınlanma Çağı insanları, [...] Orta Çağlar'ı değerlendirirken tam bir ittifak içindeydiler. Batı Roma İmparatorluğu'nun çöküşünden 16. yüzyıla kadar geçen zaman, bir fakirlik, baskı, cehalet, karanlık dönemi olarak görülmüştür 


\title{
$\operatorname{arts}=$
}

\begin{abstract}
...Kendilerinin Fransızcada siecle de lumieres (Işıklar Çağı), Almancada Aufklarung (Aydınlanma) sözcükleriyle tanımlanan bir dönemde yaşadıklarını düşünüyorlardı. Onlara göre ve haklı olarak, insanlık nihayet kendini geçmişte bir sürü kör zulüme yol açmış olan önyargıllardan ve hurafelerden görünür biçimde kurtarmaktaydı" (Hampson, 1991, s. 102).
\end{abstract}

Aydınlanma felsefesi akılcı olduğu kadar bilimcidir de. Bilim, Aydınlanma döneminde 'en üstün zihinsel otorite' (Fitzpatrick \& McCalman, 2004, s. 10) kabul edilmiştir. Bu aynı zamanda insan aklına güvenin bir gereği olmuştur (Fitzpatrick \& McCalman, 2004, s. 110). Bu açıdan, Aydınlanma ile ilgili olarak Urgan'ın tespiti önemlidir. Urgan, Aydınlanmanın 18. yüzyıldaki etkisini toplum üzerindeki yansımalarını anlatırken, bu dönem insanlarının "kurdukları düzenden ve kendilerinden hoşnut, toplumlarını kusursuz sanan, her alanda başarılarına tam bir güven duyan, yenilik istemeyen kişiler olarak tanımlar ve onlara bakılacak olursa, bilim, sağduyu ve akıl sayesinde çözümlenemeyecek sorun yoktu" (Urgan, 2004, s. 403) tespiti dile getirir. Dolayısıyla Aydınlanmanın ve onunla özdeşleşen görüşler bütününün halk arasında kolayca yayılma imkânı buımasının sebebi de anlaşılmış olmaktadır. Bir başka deyişle, Aydınlanma yalnızca entelektüel çevrelerle sınılanmış bir akım olarak kalmamış, halkın sıklıkla bir araya geldiği yerlerde tartışılmış ve kısa sürede yaygınlaşması sağlanmıştır.

17. yüzyıl, bilhassa bilimde meydana gelen gelişmeler açısından oldukça önemli bir yüzyıldır. Bu yüzyıl bilginin ve insan yaşamının niteliğinde ve niceliğinde radikal değişikliklere yol açan önemli keşiflerin gerçekleştiği, önemli ilerlemelerin yaşandığı, Bacon, Kepler, Galiéo, Descartes, Pascal, Newton gibi son derece önemli filozof/bilim insanlarının yetiştiği bir zaman dilimini temsil etmektedir. Bilimde gerçekleşen gelişmeler, doğanın işleyişini anlamaya bağlı olarak elde edilen bilgiler doğrultusunda doğanın işleyişini kontrol altına alma çabalarına yol açmıştır. Böylelikle hukuk ile Tanrı arasında kurulu olan mevcut ilişki zayıflamaya, siyaset ile din arasındaki güçlü bağlar kopmaya başlamış; bunların yerine "doğal hukuk" anlayışı gelişmiştir. Evreni ve hayatı anlamlandırmada ve yönlendirmede etkili olan dinsel anlayışlardan uzaklaşıldıkça, akıl daha bir önem kazanmaya ve sürecin temel referansı olmaya başlamıştır. Bilhassa dinde oluşan yenileştirme girişimleri ile dinsel düşünce bireysel ve toplumsal hayatttan gittikçe uzaklaşmıs ve Aydınlanmacı kabuller eşliğinde düşünce ve eylemlerde meşruiyet referansı olma gücünü kaybederken siyasal sistemdeki egemenliğini de kaybetmeye başlamıştır. Tanrı olgusunun gerek insan gerekse doğa 
ile irtibatını kesen aydınlanma düşüncesi (Cox, 1990, s. 21) ortaya attığı ilerleme mitinden hareketle siyasal, toplumsal ve felsefi bütün yönleriyle doğayı fethetmeyi ve insanı ihtiyaçları karşısında ikincil konuma indirgemeyi amaçlar (Mestroviç, 2004, s. 84). Bu düşüncenin batılı insanı getirdiği nokta, topyekûn maddi faydanın üstünlüğü düşüncesini benimsemek olmuştur.

Kuşku yok ki, Aydınlanma Çağı olarak isimlendirilen 18. yüzyılda gerçekleşen değişim ve oluşum son derece kapsamlı ve derinlikli bir değişim ve oluşumdur. Bu nedenle örneğin Beales, tarihin hiçbir döneminde 18. yüzyılda meydana gelen temel değişikliklerden daha önemli gelişmelerin yaşanmadığını belirtirken önemli bir tespitte bulunmuş olmaktadır. 17. yüzyıldaki Bilim Devrimi'yle ortaya çıkan bilgi yayıldıkça, Aydınlanma hemen bütün Avrupa ülkelerinde üst sınıfların tutumlarında radikal değişikliklere yol açmıs ve Kilise ile Kilisenin temsilcisi olduğu teolojisinin gücü hiçte yavaş olmayan bir hızda ortadan kaldırımıştır. 'ilerleme' ilkesini sürekli göz önünde bulunduran, kaynağını 17. yüzyılda meydana gelen bilimsel gelişmelerden alan ve bu gelişmeleri daha ileriye taşıma amacı güden Aydınlanma, olaylara ve gerçeklere sistematik biçimde yaklaşmış, doğayı da yine bilimsel bir yaklaşımla inceleme yolunu seçmiştir. Akla uygunluk ve düzen ilkeleri doğrultusunda hareket ederek kuşkucu tavrını hemen her fırsatta ortaya koymuş ve otoritenin değişik biçimlerinin sorgulanmadan kabulüne karşı çıkmıştır. Aydınlanma, insan aklını ve davranışını sorgulayan ve sınırlayan hemen her türlü görüşün şiddetle karşısında yer alarak bunları insan ilerleyişinin önünde engel kabul etmiş ve bu sınırlamaları ortadan kaldırma yolunda çaba sarf eden güç olmaktan büyük bir heyecan duymuş; adeta yüzyılların çözüm bulamadığı sorunları çözme iddiasıyla ortaya çıkmıştır (Yavuz ve Geçikli, 2008, s. 172).

Aydınlanmaya uzanan süreci detaylı bir şekilde araştırmış bulunan Paul Hazard'ın Ortaçağ-Yeniçağ ilişkisi veya Aydınlanmanın inşa süreci ile ilgili tespiti; bir başka söyleyişle de Kilisenin inanç ve uygulamalarına bağlı olarak yaşananları resmetmesi açısından oldukça önemlidir:

"Uzun zamandır bütün kudret rahiplerin elinde kalmışł. Bunlar yeryüzünde iyilik, adalet ve kardeşçe sevginin hâkim olacağını vadettiler, ama vaatlerini yerin getirmediler. Hakikat ve saadet mükafatlarının konduğu bir yarışta kaybedenler onlar oldu. Artık sahayı terk etmekten başka yapacak bir şey yoktu. Güzellikle giderlerse ne ala, ama gitmezlerse zorla atılacaklardı. Bütün beşeriyet ailesine iyi bir sığınak olmamış bulunan eski binanın yıkıması 


\title{
arts $s$
}

\begin{abstract}
gerekiyordu. İlk iş bir yıkım işiydi.. Bu iş iyice bitirildikten sonra da yapım işi geliyordu; müstakbel sitenin temelleri kurulacaktı. Ama en az bunun kadar önemli ve acil bir vazife de insanı ölümün öncüsü olan bir şüpheciliğe düşmekten kurtarmak üzere, insanlığı hep yanlış yola götürmüş metafizik rüyaları bertaraf eden ve bizim hudutlu gücümüzün ulaşabileceği, bizi memnun etmeye yetecek olan 'gerçekler üzerine teksif edilmiş bir felsefenin' kurulmasıydı. Illahi müeyyidesi olmayan bir 'siyasi sistem', esrarsız bir 'din', dogmasız bir 'ahlak kurmak gerekti'. ilim sırf bir zihin eğlencesinden daha fazla bir şey olmalı, tabiat kuvvetlerini insanlığın hizmetine verebilecek bir kudret kazanmalıydı" (Hazard, 1981, s. 18, 19).
\end{abstract}

\section{İdeolojinin Bilim-Din Ekseninde Konumlanması}

1789 Fransız Devrimi, inşa süreci birkaç yüzyıl geriye giden fakat Aydınlanma çağının kitaplarında ve tarihe kaydedilmiş siyasal/felsefi/toplumsal konuşmalarda ortaya konan yeni (modern) zihniyetin ve düşüncenin kendisini bireysel ve toplumsal hayatta somut şekilde ortaya koymasının tarihi olarak özel bir öneme sahiptir. Oluşumunda en az beş yüz yıllık ekonomik, siyasi, toplumsal ve dini faktörlerin etkisi vardır. Yaklaşık aynı kulvarda olmak üzere İngiliz ve Amerikan devrimlerinin daha önce gerçekleşmesine rağmen, bu dönemde gelişen insan düşüncesine ait siyasal ve toplumsal anlayış, özellikle Fransız Devrimi sonrasında hızla yayılan bir ideoloji hâline gelmiştir. Hiç kuşkusuz yeni zihniyet ve yaşam biçimi (modernlik) farklı zamanlarda farklı ülkelerde görece bazı farklılıklara sahip oldu. Ancak tüm farkllıklara rağmen modernliğin ilk sayılabilecek toplumsal bir prototipi olarak ayrıcalıklı yerini hep koruya geldi.

Fransız Devrimi'nin en karakteristik özelliklerinden birisinin, modern zihniyet ve yaşamın varoluş gerekçesi de olan 'süregelene/geleneksele tepki' özelliği olduğu kolaylıkla söylenebilir. Devrime giden süreçte süregelen ve dolayısıyla gelenekselleşmiş tüm şeylere (Ancien Regimé) tepki verilmiş, devrimle birlikte 'yeni olan' inşa edilmeye başlanmıştır. Bu konuda Devrim sonrasında gerçekleştirilen bir uygulama sembolik anlamıyla son derece önemlidir. Paris'teki Katolik dininin en önemli sembollerinden birisi olan Notre Dame Katedrali, modern siyasal devrimin hemen sonrasında referansı insan olan ve aşkın olanla irtibatını kesmiş bu yeni 'din'e atıfla 'Akıl tapınağı' (Bayet, 1970, s. 104) olarak isimlendirimiştir.

Aydınlanma filozoflarının öğrencileri olan ve gerek yazılarında gerekse konuşmalarında amaçlarını, yurttaşları Ancien Régime'in "karanlığından" kurtarıp her bakımdan "özgür kılmak" biçiminde açıklayan Fransız devrimini gerçekleştiren 
burjuva liderleri, devrimin ilk birkaç yılında da sözlerinin gereğini uygulamaya koydular. Bu birkaç yılda gerçekleşenler bir tarihçinin ifadesiyle "büyük bir heyelanının önündeki setin kaldırıması gibi bir şeydi" (Roberts, 201 1, s. 420).

Fransız devrimi, genel kabul gördüğü üzere, siyasal bir devrim olmasının yanı sıra, en az o kadar da bir 'din' devrimi olduğu rahatlıkla söylenebilir (Aulard, 2011 , s. 2, 649-685; Gaxotte, 1962, s. 242-286; Bayet, 1970, s. 100-143; Aster, 2004, s. 222-224). Geleneksel bir din olarak Katoliklik toplumsal yaşamın neredeyse tüm katmanlarında, bireysel yaşamın ise pek çok alanında etkisizleşecek, onun yerine ismi din olmayan ama işleviyle dinleşecek olan "modern bir din" (ideoloji/dünya görüşü) gelecektir. Bu tespitin pek çok referanslarından birkaç örnek hatırlanacak olunursa; İsmi ilk hatırlanacaklardan birisi Kant (1724-1804) 'tır. Kant, modern zihniyet ve yaşam biçimini, kendisinin icat ettiği sözcük üzerinden 'dünya görüşü' olarak nitelemiştir. Kant, 'dünya görüşü'nü, 'Yargı Gücünün Eleştirisi' isimli kitabında Almanca iki kelimeyi birleştirerek icat etmiş (Weltanschauung: welt: dünya; anschauung: anlayış, görüş) ve modernliğin önemli bir özelliği olarak takdim etmiştir. İçeriden bazı itirazlar olsa bile, 'dünya görüşü' nitelemesi konuyla ilgilenen ve daha da önemlisi modernliğin inşasında rol alan birçok entelektüel tarafından kolaylıkla benimsenmiş ve anlam alanı netleştirilmeye çalışımıştır. Örnek vermek gerekirse, Fichte'ye (1762-1814) göre modernlik evren ya da gerçeklik hakkında 'bütüncül bir görüş' olup, 'dünya görüşü' olması bu özelliğini ifade etmektedir. 'Dünya görüşü' olma durumunu oldukça detaylı sayılabilecek bir şekilde açıklayan Freud (1856-1839), bu açıklamalarıyla modernliğin niteliğini ve kapsamını izah etmiştir. Freud'un konuya ilişkin açıklaması şöyledir:

\footnotetext{
"Dünya görüşü ile ifade etmek istediğim şey, kapsamlı bir hipotez ile varlığımızın bütün sorunlarına kapsamlı bir çözüm sunan, bu bağlamda hiçbir soruyu cevapsı bırakmayan ve ilgili olduğumuz her şeyin yerli yerine ołurduğu bir kurgudur. Böylesi bir dünya görüşüne sahip olmak, insanlığın idealize ettiği arzularından birisidir. İnsan böyle bir şeye inandığında kendini güvende hisseder, neyin peşinde koşması gerektiğini, duygularını, çıkarlarını en iyi şekilde nasıl tanzim etmesi gerektiğini bilir" (Freud, 1976, s. 158).
}

İdeoloji kavramının doğduğu ortam ve sürecin başlarında kazandığı anlam, kendisinden beklenen işlev kısaca budur. İdeoloji bu ortamda 'yeni' zihniyet ve yaşamın bir gereği ve inşa edicisi olarak doğmuştur. İdeolojinin doğuş şartlarını 'Ideology and Cultural Identity' isimli kitabında araştırmış bulunan Jorge Larrain'in tespitine göre ideoloji, burjuvazinin feodaliteye karşı verdiği ilk mücadeleler sırasında 


\section{arts}

geleneksel aristokrat toplumda ortaya çıkmış ve 18. yüzyıl Aydınlanmacılığının felsefe ve kültür ortamında üretilmiştir. Ayrıca tarihsel bağlam göz önünde bulundurulduğunda, ideolojinin "akla derin inancı talep eden bir düşünceler bilimi" ve "eski düzene karşı verilen mücadelede kullanılan eleştirel bir silah" anlamlarını içerdiğini görülmektedir (Larrain, 1994, s. 23-46). Tüm bu zihinsel ve tarihsel izleri ideoloji sözcüğünün ilk kullananı durumundaki Tracy'nin yazılarında açıkça görmek mümkündür. İdeoloji, Fransız Devrimi günlerine ait ilk kullanımlarında "herkese doğru düşünme imkânı sağlamak için kullanılacak fikir bilimi (study of ideas)" (Mardin, 2006, s. 10) olarak anlamlandırımıştır. Bir diğer ifadeyle "fikirlerin metodolojik ve bilimsel analizi" olarak nitelendirilmiştir (Fox, 2006, s. 355). Dolayısıyla söz konusu kullanımda olumlu ve işlevsel bir anlamı vardır. 18. yüzyılın son on yılını takiben, özellikle eğitimin denetlenmesi konusunda Katolik Kilisesi'ne karşı yürütülen şiddetli bir mücadelenin içerisinde bulunmuş bir kişi olarak Tracy, "fikirlerin doğal kaynağını araştıracak" yeni bilimi tanımlamak için önerdiği ismin "dini herhangi bir lekeden arınmış olmasına" özel bir önem vermiş ve bu bakımdan metafizik ve psikoloji sözcüklerini yetersiz bulduğu için tercih etmemiştir. $O$, inşa edilmekte olan "bilim" ile düşüncelerin duyumlardan türemesinin nedenlerinin kesin bilgisine ulaşmayı amaçlıyordu. Dolayısıyla doğuştan gelen bilgi anlayışlarını reddediliyordu; yani fikirler dönüştürülmüş duyumlardı. Tracy, insan zihninin fizyolojik bir temeli olduğunu göstererek, ideolojiyi zoolojinin bir dalı olarak tanımlamıştı. Aynı aşııı empirist çizgideki Bacon, Descartes, Newton, Lavoisier ve Condillac gibi, Tracy de bu tür analizlerin içeriklerinin bilimsel prosedürlere göre dikkatle listelenerek detaylandırıması gerektiğini ileri sürmüştü (Vincent, 2006, s. 3).

\section{SONUÇ}

Bugünün dünyasında iktidar ve güç ilişkilerden, siyasal ve ekonomik sistemlerden, yaşam tarzlarından, varlığın ve yaşamı anlamlandırma tarzlarından, düşünce karşıtıklarından bahsedilirken sıklıkla işitilen sözcüklerden birisi 'ideoloji' dir. İdeoloji söz konusu veya benzeri konuların ve durumların değerlendirilmesinde, anlamlandırımasında veya eleştirilmesinde hemen her zaman kullanılan bir sözcük. Modern zamanlara ait olan bu sözcük, Aydınlanma çağı Fransa'sında, siyasal devrimin öncülüğünde yürütülen din-tanrı, gelenek, kilise, inanç, felsefe, gerçeklik tartışmalarının son derece yoğun yürütüldüğü bir ortamda doğdu. 
İdeoloji, sözcük olarak 18. yüzyılın sonlarına tarihlenmekle birlikte kavramsal geçmişi Platon'a kadar gerilere uzanıyor. Platon 'soylu yalan' kavramlaştırması üzerinden devlet, toplum, siyaset, iktidar, güç ilişkilerini tartışırken ideolojinin de öncü kavramsal temelini inşa etmiş olur. Daha sonra birçok filozof ve siyasetçi ideolojinin kavramsal inşasının önemli durakları olurlar. Bunlar arasında Francis Bacon, Étienne Bonnot de Condillac ve Claude Adrien Helvétius isimleri özel bir öneme sahiptir. Bacon, 'idol' sözcüğü ile kavramlaştırdığı algı, anlayış ve düşünüş biçimlerinin gerçekliği kavramayı engelleyen işlevlerini anlatırken bir düşünce, algılama, inanma şablonundan bahseder ve niteliğiyle değilse bile işleviyle gelecekte inşa edilecek ideolojiyi işaretler. Olumsuz anlam ve işleviyle ideolojinin kavramsal temelinde bir alan daha inşa olunur. Condillac ve Helvétius ise John Locke'dan esinlenen düşünceleriyle bilginin kaynağını ve oluşum sürecini, zihin, duyum, nesne faktörlerini tartışıllarken ve bu bağlamda felsefi tespitlerde bulunurlarken ideolojinin doğuşuna uzanan süreçte kavramsal inşaya önemli bir katkı sağlarlar. Devrim Fransa'sında devrimin kapsamını ve yönünü belirlemeye çalışan ve kendilerini 'ideologlar' olarak isimlendiren topluluğun önemli temsilcilerinden Destutt de Tracy ise kendi zamanına kadar farklı bağlamlarda gündeme gelmiş görüş, tanımlama ve tespitlerden hareketle 'ideoloji' sözcüğünü icat eder. Sözcüğü, nesnel gerçekliğe ulaşmanın yöntemi olarak nitelediği bilimin düşünceye uyarlanmış tarzının ismi olarak kullanır. Bu kullanımıyla, ideolojiye yönelik olumlu yaklaşımın gereğine uygun olarak olumlu ve kapsamlı işlevler yükler.

Platon'un 'soyluyalan' sözcüğünde kısmen olumsuz birçağrışımda bulunmakla birlikte işlev açısından tamamıyla olumlu bir durumun ismi olan 'ideoloji', Bacon'da ise 'idol' sözcüğü bağlamında gerçekliğe ulaşmayı ve anlamayı engelleyen işleviyle tamamıyla olumsuz bir anlama sahiptir. Fakat söz konusu olumlu veya olumsuz şeyin herkes tarafından kabul görecek ismi henüz konmamıştır. 'Soylu yalan' veya 'idol' ise genel kullanım ve kabule dönüşmez. Tracy tarafından sözcük olarak icat edilişi öncesinde anlamsal ve işlevsel açıdan sahip olduğu bu çelişik nitelikler Tracy'nin anlamlandırmasında tamamıyla olumlu bir boyuta evrilir. O artık 'düşünce bilimi' anlamına gelen 'ideoloji' ismiyle gerçekliğin yegâne yöntemi olan bilime ilişkin bir şeydir. Düşüncede gerçekliğe ulaşmanın yolun ve tarzın ismidir.

Tracy tarafından 'düşünce bilimi' anlamında kullanılan ideoloji kısa süre 


\section{$\operatorname{arts}=$}

sonra Napoleon Bonapart tarafından 'demogoji', 'gerçekliğin çarpıtılmış hali', 'söz salatası' anlamlarında kullanılarak hem sözcüğün kendisini hem de özelde Tracy'yi, genelde ise 'ideologlar' topluluğunu sert şekilde eleştirir (Örs, 2009: 8-9). Böylelikle olumlu-olumsuz, basit-karmaşık, dar-geniş boyutlu anlam ve niteliklerde farklı ideoloji tanımları yapılmaya, görüşleri dillendirilmeye başlanır. Fakat tüm yaklaşım, anlayış, değerlendiriş farklılıklarına rağmen ideoloji hep gündemin en popüler sözcüklerinden birisi olmuş ve halâ olmaya devam etmektedir.

\section{KAYNAKÇA}

Allard, E., (1971). Institutionalized Radicalism in Decline of ıdeology. California: University of California Press.

Althusser, L. (2003). İdeoloji ve Devletin Ideolojik Aygıtları. (Çev. Y. Alp, M. Özışık). İstanbul: İletişim Yayınları.

Althusser, L. (2004a). Lenin ve Felsefe. (Çev. B. Aksoy, E. Tulpar, M. Belge). İstanbul: İletişim Yayınları, İstanbul.

Althusser, L. (2004b). Sanat Üzerine Yazılar. (Çev. A. Tümertekin, Z. İlkgelen). İstanbul: İthaki Yayınları.

Aster, E. V. (2004). Fransız İhtilali'nin Siyasi ve Sosyal Fikirleri. (Çev. Ş. Şenel). İstanbul: Phoenix Yayınları.

Aulard, A. (201 1). Fransa İnkılâbının Siyasi Tarihi. (Çev. N. Poroy). Ankara: Türk Tarih Kurumu.

Bayet, A. (1970). Dine Karşı Düşünce Tarihi. (Çev. C. Süreya). İstanbul: Varlık Yayınları.

Budak, A. (2007). Osmanlı Modernleşmesi ve Edebiyat. Dumlupınar Üniversitesi Sosyal Bilimler Dergisi, (18).

Bulut, Y. (201 1). İdeolojinin Tarihçesi. Sosyoloji Dergisi, 3(23), 183-206.

Condillac, E. B. (1989). Duyumlar Üzerine Inceleme. (Çev. M. Katırcıoglu). İstanbul: MEB Yayınları.

Condillac, E. B. (1992). Insan Bilgilerinin Kaynağı Üzerine Inceleme. (Çev. M. Katırcıoglu). İstanbul: MEB Yayınları.

Cox, H. (1990). The Secular City. New York: Publishing Company.

Çelik, N. B. (2005). İdeolojinin Soykütüğü: Marx ve İdeoloji. Ankara: Bilim ve Sanat Yayınları. 


\section{arts $=$}

Çiğdem, A. (1997). Akıl ve Toplumun Özgürleşimi. Ankara: Vadi Yayınları.

Eagleton, T. (2005). İdeoloji. (Çev. M. Özcan). İstanbul: Ayrıntı Yayınları.

Edelman, G. (2004). Enlightenment and the Intellectual Foundations Of Modern Culture. New Haven: Yale University Press.

Fiske, J. (1996). Iletişim Çalışmalarına Giriş. (Çev. S. İrvan). Ankara: Bilim ve Sanat.

Fitzpatrick, J. Ve McCalman, K. (2004). The Enlightenment World, Routledge.

Fox, R. (2006), "Corporations' Ideologies: A New Subfield of Study of Corporate Communication". Corporate Communications: An International Journal, 11 (4), 353-370.

Freud, S. (1976). The Question of a Weltanschauung. (in) Newilntroductory Lectures on Psychoanalysis and Other Works, C. XXII, New York: Norton and Company.

Gaxotte, P. (1962). Fransız intilali tarihi. (Çev. S. Tiryakioğlu). İstanbul: Varlık Yayınları.

Gökberk, M. (1974). Felsefe Tarihi. İstanbul: Remzi Kitapevi.

Gramsci, A. (1997). Hapishane Defterleri, (Çev. A. Cemgil). İstanbul: Belge Yayınları.

Güngör, N. (2011). Iletişim (Kuramlar, Yaklaşımlar). Ankara: Siyasal Kitapevi.

Hall, S. (2014). Bilimin Geri Tarafı: İdeoloji ve 'Bilgi Sosyolojisi'”. Şahan, C. (der). İdeoloji Üzerine: Eleştirel İdeoloji Analizleri. İstanbul: Pales Yayınları.

Hall, S. ve Jacques, M. (1995). Yeni Zamanlar. (Çev. A. Yılmaz). İstanbul: Ayrıntı Yayınları.

Hampson, N. (1991). Aydınlanma Çağı, (Çev. J. Parla). İstanbul: Hürriyet Vakfı Yayınları.

Hazard, P. (1981). Batı Düşüncesindeki Büyük Değişme. (Çev. E. Güngör). İstanbul: Tur Yayınları.

Heywood, A. (2007). Siyasi İdeolojiler: Bir Giriş. (Çev. A. K. Bayram). Ankara: Adres Yayınları.

Kant, I. (1983). Aydınlanma Nedir?' Sorusuna Yanıt. Felsefe Yazıları. 6. Kitap., İstanbul: Yazko.

Laclau, E. (1998). Ideoloji ve Politika. (Çev. H. Sarıca). İstanbul: Belge Yayınları. Larrain, J., (1994). İdeoloji ve Kültürel Kimlik. (Çev. N. Nur). İstanbul: Sarmal Yayınevi. 


\section{arts $=$}

Mardin, Ş. (2006). Ideoloji. İstanbul: Illetişim Yayınları.

Marshall, G. (1999). Sosyoloji Sözlüğü. (Çev. D. Kömürcü, O. Akınhay). Ankara: Bilim ve Sanat Yayınları.

Marx, K. \& Engels, F. (2004). Alman İeolojisi. (Çev. T. Ok, O. Geridönmez). İstanbul: Evrensel Basım Yayın.

Meriç, C. (1970). İdeoloji. İstanbul Üniversitesi Sosyoloji Dergisi, 2(21-22), 119 142.

Mestroviç, G. S. (2004). Uygar Barbarlık. (Çev. M. Özay). İstanbul: Açllım Kitap.

Örs, H. B. (2009). Postmodern Dünyada İdeolojinin Dönüşümü, i.ü. Siyasal Bilgiler Fakültesi Dergis, 40, 1-12.

Özlem, D. (1990). Max Weber'de Bilim ve Sosyoloji, İstanbul: İnkılap Kitapevi. Paine, T. (2012). Akıl Çağı. (Çev. A. İ. Dalgıç). İstanbul: İş Bankası Yayınları.

Platon. (2005). Devlet. (Çev. C. Saraçoğlu, V. Atayman). İstanbul: BordoSiyah Yayınları.

Purvis, T. \& Hunt, A. (2014). Söylem, ideoloji, Söylem, ideoloji, Söylem, ideoloji... (Çev. S. Coşar). Moment Dergi, 1 (1), 9-36.

Reboul, O. (1991) Eğitim Felsefesi. (Çev. I. Gürbüz). İstanbul: İletişim Yayınları.

Roberts, J. M. (2011). Avrupa Tarihi. (Çev. A. Demirkaynak). İstanbul: İnkılap Yayınları.

Taylor, C. (2009). Seküler Çağ. (Çev. D. Körpe). İstanbul: İş Bankası Yayınları.

Tracy, D. D. (1956). Elements d'Idéologie. Paris: Montchretien.

Urgan, M. (2004). Ingiliz Edebiyatı Tarihi, İstanbul: Yapı Kredi Yayınları.

Van Dijk, T. A. (2019). İdeoloji: Multidisipliner Bir Yaklaşım. (Çev. A. Demir). Ankara: Hece Yayınları.

Vincent, A. (2006). Modern Politik Ideolojiler. (Çev. A. Tüfekçi). İstanbul: Paradigma Yayınları.

Williams, R. (1990). Marksizm ve Edebiyat. (Çev. E. Tarım). İstanbul: Adam Yayınları.

Williams, R. (2007). Anahtar Sözcükler: Kültür ve Toplumun Söz Varlığı. (Çev. S. Kılıç). İstanbul: İletişim Yayınları.

Yavuz, M. E. \& Geçikli, K. (2008). Gotik Romanda Aydınlanma Karşıtlığı. Cumhuriyet Üniversitesi Sosyal Bilimler Dergisi, 32(1), 171-188.

Yaylagül, L. (2014). Kitle Illetişim Kuramları. Ankara: Dipnoł yayınları.

Yıldırım, C. (1985). Bilim Felsefesi. İstanbul: Remzi Kitapevi. 